\title{
PENGARUH BRAND AWARENESS TERHADAP KEPUTUSAN PEMBELIAN PRODUK BRAND FASHION MERCHÈ DI KALANGAN FOLLOWERS INSTAGRAM MERCHE.ID
}

\author{
Aldila Salsha Nabila, Nelly Nailatie Ma'arif \\ LSPR Communication and Business Institute Jakarta, Indonesia \\ Email: aldilanabilaa@gmail.com,nelly.nm@1spr.edu
}

\begin{abstract}
Abstrak
Merchè merupakan sebuah merek lokal yang menawarkan produk fashion perempuan dengan segmentasi usia remaja dan dewasa muda. Guna menunjang pemasaran produk-produknya, Merchè memanfaatkan Instagram sebagai media untuk membangun awareness followers yang akhirnya di dorong untuk dapat melakukan pembelian pada produk Merchè. Untuk itu penelitian ini bertujuan untuk mengetahui seberapa besar pengaruh brand awareness terhadap keputusan pembelian produk Merchè di kalangan followers Instagram merche.id. Penelitian ini menggunakan metode eksplanatif dengan pendekatan kuantitatif. Populasinya berjumlah 452.000 akun followers Merchè dengan sampel sebanyak 100 akun followers yang dipilih melalui simple random sampling. Teknik pengumpulan data melalui kuesioner dan studi literatur. Hasil penelitian menunjukkan bahwa pengaruh signifikan brand awareness terhadap keputusan pembelian produk Merchè di kalangan followers Instagram merche.id. Nilai koefisien siginifikansinya sebesar 0,501 yang berarti pengaruhnya cukup signifikan. Brand awareness followers pada merek Merchè berkontribusi sebesar 50,1\% terhadap keputusan pembelian produk Merchè dan sisanya 49,9\% berasal dari faktor lain.
\end{abstract}

Kata Kunci: brand awareness; keputusan pembelian; new media; media sosial instagram

\section{Abstract}

Merchè is a local brand that offers women's fashion products with segmentation among adolescents. To support the marketing of their fashion products, Merche uses Instagram as a marketing medium to build followers' awareness which is ultimately encouraged to make purchases on Merchè products. For this reason, this study aims to determine how much influence brand awareness has on purchasing decisions for Merch products. This study uses an explanatory method with a quantitative approach. The population is 452,000 followers with 100 sample of followers, selected through simple random sampling. Data collection techniques through questionnaires and literature study. The results show that there was a significant effect of brand awareness on purchasing decisions for Merchè products. The coefficient of significance is 0.501, which means that the effect was quite significant. Brand awareness of Merchè brand contributed 50,1\% to followers purchase decision and the remaining 49,1\% comes from other factors.

$\begin{array}{ll}\text { How to cite: } & \text { Nabila, A. S.., \& Ma'arif, N. N., (2021) Pengaruh Brand Awareness Terhadap Keputusan } \\ & \text { Pembelian Produk Brand Fashion Merchè Di Kalangan Followers Instagram Merche.Id. } \\ & \text { Syntax Idea, 3(9), https://doi.org/10.36418/syntax-idea.v3i9.1458 } \\ & 2684-883 X \\ \text { E-ISSN: } & \text { Ridwan Institute } \\ \text { Published by: } & \end{array}$


Keywords: brand awareness; purchase decision; new media; social media; instagram

Received: 2021-08-22; Accepted: 2021-09-05; Published: 2021-09-20

\section{Pendahuluan}

Perkembangan teknologi informasi semakin memicu perubahan budaya konsumen dalam memanfaatkan informasi dari internet. Akses internet pun dilakukan dengan beragam tujuan seperti mencari informasi melalui kegiatan browsing pada berbagai situs web, bermain game online, menonton film, hingga bersosialisasi menggunakan media sosial yang saat ini menjadi sorotan bagi masyarakat global di berbagai wilayah termasuk Indonesia sendiri. Dalam laporan yang dipublikasikan oleh We are Social dan Hootsuite (Susyanti \& Wahono, 2018), disebutkan bahwa negara di posisi tiga teratas yang mengalami pertumbuhan pengguna internet sebesar 17 persen per tahun aadalah Indonesia. Data ini menunjukkan bahwa setiap tahunnya terdapat 25,3 juta pengguna internet baru di Indonesia. Dalam laporan tersebut juga disebutkan bahwa rata-rata pengguna internet di Indonesia mengakses internet selama 8 jam per hari. Di level global, Indonesia adalah negara dengan rata-rata waktu akses internet terlama di peringkat ke delapan. Sementara untuk negara teratas untuk rata-rata pengguna internet adalah Filipina. Waktu akses internet rata-rata pengguna filipina adalah sekitar 9 jam dan 45 menit. Durasi ini jauh di atas rata-rata dunia yang membukukan angka 6 jam dan 43 menit.

Dari banyaknya akses internet di Indonesia, laporan yang dipublikasikan We are Social dan Hootsuite menunjukan bahwa penggunaan internet rata-rata untuk gadget atau ponsel adalah dengan peruntukan mengakses social media sebanyak $80 \%$ nya. Ditemukan juga bahwa durasi akses internet untuk gadget ponsel mencapai 3 jam 46 menit alokasi waktu untuk mengakses sosial media, sekitar $80 \%$ dari total waktu akses selama 4 jam 46 menit. Jika kita mengaitkan data ini dengan perilaku sosial masyarakat Indonesia, dapat dikatakan bahwa masyarakat Indonesia memusatkan atensi yang tinggi ke dalam sosial media. Tidak heran jika penemuan atau data selanjutnya yang menunjukkan aktivitas sosial media oleh masyarakat Indonesia akan mendapatkan peringkat yang tinggi di level global dibandingkan dengan masyarakat dunia lainnya. Ekspos terhadap Sosial Media di Indonesia ditemukan memasuki capaian angka 59 persen. Angka ini menunjukkan bahwa telah lebih dari separuh masyarakat Indonesia yang aktif menggunakan internet. Jika dibandingkan dengan tahun sebelumnya, angka ini telah bertumbuh sebanyak 8,1\%. (Susyanti \& Wahono, 2018).

Diketahui bahwa pengguna Internet yang mengakses media Instagram telah mencapai sekitar angka 1 Miliar untuk level global. Dibandingkan dengan angka tersebut, Indonesia memiliki pengguna Instagram sebesar 63 juta jiwa dan angka tersebut berada di urutan tertinggi ke tiga di skala global. Melihat kembali angka pengguna Internet di Indonesia, dapat dikatakan bahwa 1/3 dari pengguna internet di Indonesia mengakses media Instagram. Dengan kata lain, untuk setiap 10 pengguna internet di Indonesia, kita dapat menjangkau 3 orang melalui media instagram. (Susyanti \& Wahono, 2018). Berdasarkan data daririset We are Social dan Hootsuite 
tahun 2020 sebagaimana disajikan di atas mengenai jumlah pengguna dan reach Instagram di Indonesia menunjukan besarnya potensi pengguna Instagram sebagai segmen pasar di Indonesia. Instagram merupakan media sosial yang utamanya berisi mengenai konten dengan format foto atau video yang disertai dengan caption (keterangan) pendukung dari foto atau video yang diunggah. Saat ini penggunaan Instagram tidak lagi hanya untuk berbagi foto dan video pengalaman pribadi untuk rekreasi, namun juga dapat digunakan sebagai sarana promosi bisnis baik untuk satu individu saja atau organisasi berbadan hukum sekali pun (Sakinah, 2018). Awalnya Instagram adalah media yang sifatnya sekedar untuk hiburan. Namun seiring perkembangan zaman, Instagram saat ini telah mendukung fitur untuk membuat dan mentargetkan iklan kepada kalangan tertentu secara berbayar. Instagram pun mulai digunakan oleh perusahaan-perusahaan korporat yang berbadan hukum (Indriani, 2017), seperti halnya juga yang dilakukan Merchè.

Merchè adalah sebuah merek lokal (local brand) yang menawarkan produk fashion khusus perempuan dengan segmentasi utama di kalangan usia remaja dan dewasa muda. Merchè di dirikan oleh Tari uji Lestari pada tahun 2015, tetapi semat terjadi kegagalan hingga pada akhir di tahun 2017, Merchè memulai usahanya kembali. Hingga saat ini, Merchè terus tumbuh berkembang dan semakin memperluas produk fashionnya yang tidak hanya berfokus pada tas dan pakaian saja tetapi juga sepatu dan juga aksesoris (Jatilarasati, 2018).

Guna menunjang pemasaran pada produk-produk fashion yang dibuatnya, Merchè kemudian memanfaatkan berbagai pemasaran online dengan membuat website madebymerche.com yang dapat digunakan juga bagi pelanggan untuk melakukan pemesaran produknya. Selain itu, pemasaran online Merchè juga dilakukan melalui berbagai online market place dan juga memanfaatkan pemasaran melalui media sosial seperti melalui Facebook dan Instagram. Untuk media sosial, Merchè memfokuskan pada pemasaran melalui Instagram. Saat ini Merchè bahkan lebih serius menggarap berbagai konten pemasaran melalui Instagram. Merchè kemudian menjadikan Instagram sebagai media penting bagi pemasaran produk fashionnya, di mana Merchè secara khusus memiliki tim admin sendiri dalam mengurus berbagai konten pemasaran yang disajikannya di akun Instagramnya. Selama dua tahun terakhir, pengikut (followers) akun Instagram merce.id terus bertambah banyak, hingga pada 7 Agustus 2020 jumlah followers akun Instagram merce.id sebanyak lebih dari 452.000 followers. Besarnya jumlah followers Merchè di Instagram menjadi salah satu indikasi bahwa Merchè menjadikan akun Instagram sebagai media yang penting dalam melakukan berbagai kegiatan pemasaran di dalamnya.

Pemasaran online yang dilakukan Merchè seperti melalui official website pribadi, market place, dan media sosial juga sebenarnya juga dilakukan oleh beberapa kompetitor local brand yang ada seperti brand fashion This Is April yang memasarkan berbagai produk fashionnya melalui situs www.thisisapril.com, brand May Out Fit melalui situs www.mayoutfit.co.id yang lebih fokus pada produk pakaian, brand Levaya melalui situs www.levaya.id yang lebih fokus pada produk tas, atau pun brand Adorable 
Projects dalam melalui www.adorableprojects.com yang lebih menfokuskan pada produk sepatu. Semua local brand tersebut merupakan beberapa pilihan merek fashion lokal yang bersaing dengan Merchè. Kesemua brand tersebut pun gencar melakukan pemasaran melalui website, media sosial, dan market place seperti halnya yang dilakukan Merchè. Alasan peneliti untuk kemudian memilih Merchè sebagai objek penelitian, karena Merchè dapat dikatakans ebagai market leader di antara local brand yang disebutkan di atas yang namanya besar melalui pemasaran secara online.

Media sosial menjadi aspek penting dalam kaitan perusahaan dengan pelanggannya, di mana perusahaan dapat berinteraksi langsung dengan pelanggan dan calon-calon konsumen potensial melalui kedekatan interaksi media sosial. Media sosial juga dapat dimanfaatkan dalam melakukan branding oleh perusahaan melalui kontenkonten yang diunggah, sebagaimana diungkapkan (Manninen, 2017) bahwa potensi yang dipegang media sosial untuk komunikasi merek, memutuskan platform mana yang akan digunakan dan bagaimana media sosial menjadi penting bagi bisnis yang berjuang untuk menarik perhatian serta dukungan khalayak online.

Tujuan dibalik pemasaran online adalah untuk meningkatkan lalu lintas situs web. Pemasar online selalu menemukan cara baru dan inovatif untuk menghasilkan strategi untuk mempromosikan situs masing-masing (Kabani, 2013) Media digital memungkinkan terjadinya pertukaran informasi dalam berbagai bentuk. Informasi tersebut dapat untuk tujuan seperti hiburan, ilustrasi atau komunikasi.

Kajian mengenai penggunaan brand awareness dan kaitannya dengan pembelian konsumen sebelumnya telah dilakukan (Yuliati \& Maulidi, 2017) yang mengkaji tingkat brand Awareness terhadap minat Beli Apple Iphone, yang disebabkan oleh harga produk Apple Iphone yang relative lebih mahal dibandingkan dengan merek lain sedangkan fitur yang ditawarkan Apple tidak jauh berbeda dari ponsel lainnya. Hasil penelitiannya menunjukan bahwa tingkat brand awareness berada pada kategori sangat baik, besarnya pengaruh brand awareness terhadap minat beli konsumen secara stimulus sebesar 42,6\% (Yuliati \& Maulidi, 2017). Selain juga ada kajian dari (Pradana \& Yulianna, 2015) yang mengkaji tentang bagaimana brand awareness sehingga dapat mempengaruhi minat beli konsumen. Di mana hasil penelitian menunjukan bahwa ada pengaruh brand awareness terhadap minat beli konsumen pada Go Indonesia. Di sisi lain, Go Indonesia merupakan merek yang tidak di sadari konsumen, ditunjukan oleh rata-rata persentase total unaware of brand yaitu sebesar 58\% (Pradana \& Yulianna, 2015).

Kedua kajian terdahulu di atas menggunakan Piramida Brand Awareness sebagai konsep utama dalam menunjukan adanya tingkatan dalam menilai brand awareness konsumen. Bedanya dengan penelitian yang peneliti lakukan sekarang bahwa peneliti tidak hanya menunjukan pengaruhdari brand awareness pada keputusan pembelian konsumen tetapi juga menunjukan pada posisi mana awareness konsumen berada berdasarkan konsep Piramida Brand Awareness dari Aaker yang peneliti gunakan dalam menilai brand awareness di kalangan followers Instagram merche.id. 
Permasalahannya bahwa berbagai unggahan konten pemasaran Merchè yang dibangun di media sosial tidak sepenuhnya dapat menjangkau followers keseluruhan, mengingat followers memiliki hak penuh dalam mengakses Instagram menurut kebutuhannya. Untuk itu, berbagai unggahan konten pemasaran Merchè tidak selalu mendapatkan awareness followers sehingga keputusan pembelian produk Merchè di kalangan followers Instagram merche.id juga ditentukan oleh kesediaan followers untuk mengakses akun Instagram Merchè. Untuk itu penelitian ini kemudian bertujuan untuk mengetahui seberapa besar pengaruh brand awareness terhadap keputusan pembelian produk Merchè di kalangan followers Instagram merche.id.

\section{Metode Penelitian}

Penelitian ini menggunakan metode eksplanatif, dimana eksplanatif merupakan metode yang digunakan untuk menghubungkan atau mencari sebab akibat antara dua atau lebih konsep (variabel) yang akan diteliti (Kriyantono \& Sos, 2014). Metode eksplanatif menujukan upaya peneliti usaha dalam mencari variasi hubungan diantara variabel penelitian yang digunakan. Metode eksplanatif pun dilakukan dengan upaya untuk membuktikan hipotesis mengenai arah hubungan diantara variabel-variabel penelitian yang digunakan. Metode eksplanatif dalam penelitian ini diterapkan untuk mengetahui pengaruh brand awareness terhadap keputusan pembelian produk Merchè di kalangan followers akun Instagram merche.id, di mana ada proses sebab akibat yang diamati dari keberadaan variabel brand awareness terhadap variabel keputusan pembelian dalam penelitian ini. Untuk itu metode eksplanatif digunakan untuk dapat mengetahui arah dugaan yang lebih menjelaskan pengaruh di antara dua variabel penelitian tersebut.

Populasi merupakan wilayah generalisasi yang terdiri atas objek/subjek yang mempunyai kuantitas dan karakteristik tertentu yang ditetapkan oleh periset untuk dipelajari, kemudian ditarik suatu kesimpulan (Sugiyono, 2013a). Populasi dalam penelitian ini yakni followers Instagram merche.id. Jumlah followers Instagram merche.id dapat berkurang maupun bertambah setiap waktu, sehingga peneliti kemudian menentukan jumlah followers tersebut jumlah followers Instagram merche.id per tanggal 7 Agustus 2020 sebanyak lebih dari 452K (452.000) followers. Pihak Instagram melakukan pembulatan jumlah followers berdasarkan hitungan ribuan, sehingga peneliti kemudian menentukan jumlah followers dalam penelitian ini yakni sebanyak 452.000 akun yang terdatasebagai followers akun Instagram merche.id.

Setelah ditetapkan populasi maka selanjutnya dibutuhkans ampel, di mana sampel adalahsuatubagiandaripopulasi yang akanditeliti dan yang dianggap dapat menggambarkan populasinya (Soehartono, 2011). Banyaknya jumlah populasi penelitian memungkinkan peneliti untuk melakukan survey pada responden terpilih yang merupakan bagian dari populasi. Bagian populasi tersebut diwakilkan pada kumpulan responden yang disebut sampel, di mana kemudian sampel dianggap sebagai perwakilan dari populasi yang dapat menggambarkan karakteristik populasi melalui 
perwakilan sampel. Besarnya jumlah sampel pada penelitian ini ditentukan dengan menggunakan rumus (Umar, 2009) sebagai berikut:

$$
n=\frac{N}{1+N e^{2}}
$$

Dimana:

$\mathrm{n}=$ Ukuran atau besarnya sampel

$\mathrm{N}=$ Ukuran atau besarnya populasi

$\mathrm{e}=$ Persen kelonggaran karena kesalahan pengambilan sampel yang masih dapat di tolerir. Presisi tingkat kesalahan yang ditetapkan dalam penelitian ini yakni sebesar $10 \%$.

Berdasarkan rumus penentuan sampel berdsarkan rumus Slovin di atas, makan dapat di aplikasikan sebagai berikut:

$$
\begin{aligned}
& n=\frac{452.000}{1+452.000(10 \%)^{2}} \\
& n=\frac{452.000}{99,9} \\
& n=99,9 \approx \mathbf{1 0 0}
\end{aligned}
$$

Berdasarkan penerapan rumus sampel di atas dengan tingkat kesalahan 10\%, maka sampel yang terpilih dalam penelitian ini berjumlah 100 followers akun Instagram merche.id.

Setelah penentuan jumlah sampel dilakukan, maka selanjutnya perlu dilakukan penarikan sampel untuk memperjelas kepada anggota populasi mana kah yang akan dijadikan sampel penelitian. Teknik penarikan sampel yang digunakan dalam penelitian ini yaitu simple random sampling (sampel acak sederhana) untuk memberikan kesempatan yang sama pada seluruh sampel. Teknik sampling random / acak / campur dinamakan demikian karena di dalam pengambilan sampelnya, peneliti "mencampur" subjek-subjek di dalam populasi sehingga semua subjek dianggap sama. Dengan demikian maka peneliti memberi hak yang sama kepada setiap subjek untuk memperoleh kesempatan dipilih menjadi sampel (Arikunto, 2013).

Teknik pengambilan simple random sampling tersebut dilakukan karena responden berasal dari followers akun Instagram merche.id yang terdata. Akun-akun Instagram yang menjadi followers akun Instagram merche.id dapat diketahui jumlahnya dan pemilik atau pengelola akunnya memiliki kesetaraan, di mana followers tidak dibedakan atas kategori tertentu. Simple random sampling juga memberikan kesempatan yang sama bagi semua followers akun Instagram merche.id untuk dijadikan sebagai sampel penelitian.

Selanjutnya ditentukan teknik pengumpulan data, di mana dalam penelitian ini dibedakan atas dua bagian, yakni data primer (utama) dan data sekunder (penunjang). 
Data Primer merupakan data yang didapat dari sumber pertama baik dari individu atau perseorangan, melalui sebuah hasil wawancara atau pembagian kuesioner (Abdullah, 2015). Teknik pengumpul data primer kemudian peneliti lakukan melalui penggunaan kuesioner. Peneliti kemudian menggunakan kuesioner elektronik untuk melakukan pengumpulan data agar lebih efisien, di samping juga kemudahan melakukan pengumpulan data di tengah pandemik COVID-19 yang memerlukan pembatasan fisik.

Teknik pengumpulan data sekunder pada penelitian ini dilakukan melalui studi kepustakaan yang menurut (Nazir, 2014) bahwa studi kepustakaan selain mencari data sekunder yang mendukung penelitian, juga diperlukan guna mengetahui ilmu yang berhubungan dengan penelitian berkembang, sampai mana kesimpulan dan degeneralisasi yang pernah dibuat, sehingga situasi yang diperlukan dapat diperoleh.

Teknik analisis data akan menjelaskan mengenai langkah-langkah peneliti dalam mengolah data yang didapatkan di lapangan menjadi sebuah laporan hasil penelitian. Perlu adanya langkah-langkah systematis dalam mengolah data-data tersebut hingga dapat merepresentasikan hasil penelitian yang utuh. Teknik analisis data kuantitatif menurut (Arikunto, 2013) terdiri atas 3 langkah utama, yakni persiapan, tabulasi, dan penerapan data sesuai dengan pendekatan penelitian.

Skala pengukuran merupakan ketentuan dalam menentukan syarat-syarat tertentu pada alatukur. Skala pengukuran pada penelitian ini menggunakan skala Likert, di mana Skala Likert akan menjabarkan variabel yang akan diukur dalam bentuk indikator. Kemudian indikator tersebut dijadikan sebagai titik tolak untuk menyusun item-item instrumen yang dapat berupa pernyataan atau pertanyaan (Sugiyono, 2013)

Jawaban setiap item instrumen yang menggunakan skala Likert mempunyai gradasi dari sangat positif sampai sangat negatif, antara lain: a) Sangat setuju/selalu/sangat positif di beri skor 5; b) Setuju/sering/sangat positif di beri skor 4; c) Ragu-ragu/kadang-kadang/netral diberi skor 3; d) Tidak setuju/hamper tidak pernah/negative di beri skor 2; e) Sangat tidak setuju/tidak pernah di beri skor 1 (Sugiyono, 2013).

Variabel yang digunakan dalam penelitian ini adalah brand awareness sebagai variabel independent/ bebas $(\mathrm{X})$ dan keputusan pembelian produk fashion Merchè sebagai variabel dependen/ terikat (Y) yang diperasionalisasikan sebagai berikut:

Tabel 1

Operasionalisasi Variabel

\begin{tabular}{|c|c|c|}
\hline Variabel & Dimensi & Indikator \\
\hline \multirow{6}{*}{$\begin{array}{c}\text { Brand } \\
\text { awareness } \\
\text { Merchè (X) }\end{array}$} & Unaware of brand & Ketidaktahuan followers pada produk Merchè \\
\hline & & $\begin{array}{l}\text { Ketidaktahuan followers pada keunggulan } \\
\text { Merchè }\end{array}$ \\
\hline & Brand recognition & Ingatan followers pada produk Merchè \\
\hline & & Keraguan followers tentang produk Merchè \\
\hline & Brand recall & $\begin{array}{l}\text { Pengetahuan followers pada produk Merchè } \\
\text { tanpa perlu diingatkan }\end{array}$ \\
\hline & & Ingatan followers pada produk Merchè di \\
\hline
\end{tabular}




\begin{tabular}{|c|c|c|}
\hline Variabel & Dimensi & Indikator \\
\hline & & Instagram \\
\hline & Top of mind & Lebihmengingat Merchè disbanding merek lain \\
\hline & & Merchè sebagai pilihan utama followers \\
\hline \multirow{6}{*}{$\begin{array}{l}\text { Keputusan } \\
\text { pembelian } \\
\text { produk fashion } \\
\text { Merchè }(Y)\end{array}$} & Pengenalan masalah & Keinginan followers mengenal produk Merchè \\
\hline & & $\begin{array}{l}\text { Dorongan pihak lain untuk mengenal produk } \\
\text { Merchè }\end{array}$ \\
\hline & Pencarian informasi & $\begin{array}{l}\text { Membandingkan produk Merchè berdasarkan } \\
\text { pengalaman sendiri }\end{array}$ \\
\hline & & $\begin{array}{l}\text { Membandingkan produk Merchè berdasarkan } \\
\text { pengalaman orang lain }\end{array}$ \\
\hline & Evaluasi alternatif & $\begin{array}{l}\text { Pertimbangan keuntungan yang diberikan } \\
\text { Merchè }\end{array}$ \\
\hline & & Pertimbangan manfaat yang diberikan Merchè \\
\hline
\end{tabular}

Sumber: Aaker dalam Rangkuti, 2013; Kotler \& Keller, 2010; Data Olahan Peneliti, 2020.

Untuk itu uji validitas diperlukan untuk menilai kesesuaian alat pengukuran pada kuesioner sebagai intrumen penelitian, sebagaimana diungkapkan (Azwar, 2012) validitas adalah indeks yang menyatakan sejauh mana instrument akan mengukur apa yang ingin diukur validitas berasal dari kata validity yang mempunyai arti sejauh mana relevansi pernyataan terhadap apa yang diukur dalam melakukan fungsi ukurnya. Teknik validasi kuantitatif dapat dilakukan dengan melakukan pengujian pada instrument penelitian sebagaimana diungkapkan (Sugiyono, 2013) bahwa instrumen yang valid berarti alatukur yang digunakan untuk mendapatkan data (mengukur) itu valid. Valid berarti intrumen tersebut dapat digunakan untuk mengukur apa yang seharusnya diukur.

Validitas adalah sejauh mana instrumen penelitian benar-benar mengukur apa yang telah dirancang untuk diukur. Ada dua macam validitas yang dapat diukur secara statistik. Ini adalah validitas konkuren dan validitas prediktif. Keduanya dapat ditentukan dengan menggunakan Pearson r. Sebagaimana diungkapkan (Arikunto, 2013) bahwa korelasi tata jenjang yang disebut dalam istilah bahasa Inggris rankdifference correlation atau rank order correlation, digunakan untuk menentukan hubungan dua gejala yang kedua-duanya merupakan gejala ordinal atau tata jenjang. Bentuk aplikasi dari penggunaan rank-difference correlation (rho) pada penelitian ini dilakukan dengan menggunakan rumus yang dikemukakan (Arikunto, 2013) yaitu:

$$
\mathrm{rho}_{\mathrm{xy}}=1-\frac{6 \Sigma \mathrm{D}^{2}}{\mathrm{n}\left(\mathrm{n}^{2}-1\right)}
$$

Dimana:

rho ${ }_{\mathrm{xy}}=$ Koefisien korelasi tata jenjang 
D = Difference. Sering digunakan juga B singkatan dari Beda. D adalah Beda antara jenjang tiap subjek

$\mathrm{n} \quad=$ Banyaknya subjek

Pengujian validitas instrumen konstrukter sebut dipilih sebagai sarana guna melakukan pengujian validitas pada tiapitem (butir) pertanyaan atau pertanyaan yang digunakan sebagaimana diungkapkan (Sugiyono, 2013) bahwa selanjutnya apakah setiap butir dalam instrumen itu valid atau tidak, dapat diketahui dengan cara mengkorelasikan antara skor butir dengan skor total (Y). Bila harga korelasi di bawah $0,30$ (r-kritis $<0,30)$ maka dapat disimpulkan bahwa butir intrumen tersebut tidak valid, sehingga harus diperbaiki atau dibuang.

Uji validitas penelitian ini dilakukan melalui pretest pada 30 responden dengan melakukan pengujian pada seluruh jumlah item instrumen penelitian yang hasil pengujiannya sebagaimana disajikan pada table berikut:

Tabel 2

Hasil Uji Validitas

\begin{tabular}{cll}
\hline No. & \multicolumn{1}{c}{ Instrumen Penelitian } & Koefisen Korelasi \\
\hline 1. & Ketidaktahuan followers pada ragam produk Merchè & 0.796 \\
\hline 2. & Ketidaktahuan followers pada keunggulan Merchè & 0.769 \\
\hline 3. & Ingatan followers pada produk Merchè & 0.796 \\
\hline 4. & Keraguan followers tentang produk Merchè & 0.699 \\
\hline 5. & $\begin{array}{l}\text { Pengetahuan followers pada produk Merchè tanpa perlu } \\
\text { diingatkan }\end{array}$ & 0.437 \\
\hline 6. & Ingatan followers pada produk Merchè di Instagram & 0.749 \\
\hline 7. & Lebih mengingat Merchè disbanding merek lain & 0.543 \\
\hline 8. & Merchè sebagai pilihan utama followers & 0.622 \\
\hline 9. & Keinginan followers mengenal produk Merchè & 0.560 \\
\hline 10. & Dorongan pihak lain untuk mengenal produk Merchè & 0.513 \\
\hline 11. & $\begin{array}{l}\text { Membandingkan produk Merchè berdasarkan pengalaman } \\
\text { sendiri }\end{array}$ & 0.720 \\
\hline 12. & $\begin{array}{l}\text { Membandingkan produk Merchè berdasarkan pengalaman } \\
\text { orang lain }\end{array}$ & 0.515 \\
\hline 13. & Pertimbangan keuntungan yang diberikan Merchè & 0.836 \\
\hline 14. & Pertimbangan manfaat yang diberikan Merchè & 0.858 \\
\hline & & \\
\hline
\end{tabular}

Sumber dari Data Olahan Peneliti, 2020

Berdasarkan table 2. Diketahui bahwa uji validitas keseluruhan item dari instrumen penelitian memiliki koefisien korelasi lebih besar dari 0,30 sehingga seluruh 
item instrumen penelitian dinyatakan valid. Pengujian validitas dilakukan pada seluruh item dan dinyatakan valid jika memiliki koefisien validitas lebih besar dari 0.30 sebagaimana diungkapkan (Sugiyono, 2013) bahwa item yang mempunyai korelasi positif dengan kriterium (skor total) serta korelasi tinggi, menunjukan bahwa item tersebut mempunyai validitas yang tinggi pula. Biasanya syarat minimum untuk dianggap memenuhi syarat kalau $r=0.3$.

Reliabilitas dan validitas adalah konsep yang digunakan untuk mengevaluasi kualitas penelitian. Mereka menunjukkan seberapa baik metode, teknik atau tes mengukur sesuatu. Realibilitas adalah tentang konsistensi suatu ukuran, dan validitas adalah tentang keakuratan suatu ukuran (Rakhmat \& Surjaman, 2012). Penting untuk dapat menentukan reliabilitas pada alat ukur untuk dapat melihat konsistensi pengukuran pada tiap instrumen penelitian. Uji reliabilitas ini akan memberikan gambaran mengenai konsistensi instrumen penelitian sebagai alat ukur.

Uji reliabilitas pada seluruh item pertanyaan dengan data skala ordinal sebagai instrumennya, maka pengujian reliabilitas instrumen dapat dilakukan dengan teknik belah dua (split half), sebagaimana diungkapkan (Sugiyono, 2013) bahwa pengujian reliabilitas instrumen dapat dilakukan dengan teknik belah dua dari Spearman Brown (Split half).

Penilaian koefisien reliabiltas pada seluruh item pertanyaan dengan teknik split half selayaknya dapat dilakukan dengan menggunakan koefisien alpha. Pada hakikatnya koefisien alpha merupakan rata-rata semua koefisien korelasi belahdua (split half) yang mungkin dibuat dari satu alat ukur (Soehartono, 2011).

Untuk itu penggunaan koefisien alpha pun relevan untuk digunakan pada data skala ordinal dengan cara melakukan pengujian pada seluruh item instrumen pertanyaan atau pernyataan penelitian. Rumus dari koefisien alpha tersebut diungkapkan (Soehartono, 2011) sebagai berikut:

$$
\alpha=\frac{\mathrm{n}}{\mathrm{n}-1}\left(1-\frac{\Sigma \mathrm{V}_{\mathrm{i}}}{\mathrm{V}_{\mathrm{t}}}\right)
$$

\section{Dimana:}

$\mathrm{n} \quad=$ jumlah butir

$\mathrm{V}_{\mathrm{i}}=$ varian butir; tanda sigma berarti jumlah

$\mathrm{V}_{\mathrm{t}}=$ varians total nilai total

Uji reliabilitas penelitian ini kemudian dilakukan pada seluruh item instrumen penelitian secara bersamaan yang hasil pengujiannya disajikan sebagaimana pada table berikut ini: 


\section{Tabel 3}

\begin{tabular}{cc}
\multicolumn{2}{c}{ Hasil Uji Reliabilitas } \\
\hline Uji Reliabilitas & Koefisien Alpha \\
\hline Cronbach's Alpha & 0.925 \\
\hline \multicolumn{2}{c}{ Sumber: Data olahan peneliti, 2020.}
\end{tabular}

Uji reliabilitas untuk seluruh item instrumen penelitian pada penelitian ini, dinyatakan reliable karena lebih besar dari 0,6 sebagai batas minimumnya. Nilai reliabilitas dari belah dua melalui teknik alpha ini mengacu pada batas minimum sebagaimana diutarakan (Arikunto, 2013) bahwa kriteria suatu instrumen penelitian di katakan reliable bila koefisien reliabilitas $\geq 0,6$ maka dikatakan reliabel.

\section{Hasil dan Pembahasan}

Hasil penelitian yang peneliti lakukan utamanya dilakukan melalui uji regresi linier yang digunakan untuk menganalisa dan memprediksi pengaruh antara variabel independen terhadap dependen. Analisis regresi ini dapat juga digunakan untuk menunjukan arah dan besarnya hubungan diantara dua variabel penelitian, serta juga dapat menunjukan besarnya pengaruh yang diberikan dari hubungan kedua variabel tersebut. Untuk itu regresi linear digunakan untuk memberikan prediksi serta dugaandugaan terkait pengaruh brand awareness terhadap keputusan pembelian produk Merchè di kalangan followers Instagram merche.id.

\section{Tabel 4}

Pengaruh Brand Awareness Terhadap Keputusan Pembelian Merchè

\begin{tabular}{cccccc}
\hline $\begin{array}{c}\text { Jenis } \\
\text { Pengujian }\end{array}$ & $\begin{array}{c}\text { Koefisien } \\
\text { Korelasi }\end{array}$ & $\begin{array}{c}\text { Uji Koefisien } \\
\text { Determinan } \\
\left.\text { (Adjusted } \boldsymbol{R}^{2}\right)\end{array}$ & $\begin{array}{c}\text { Uji } \\
\text { Parsial } \\
(\mathbf{t}-\text {-test) }\end{array}$ & $\begin{array}{c}\text { Uji } \\
\text { Simultan } \\
\text { (F-test) }\end{array}$ & Kesimpulan \\
\hline $\begin{array}{c}\text { Pengaruh X } \\
\text { terhadap Y }\end{array}$ & 0,708 & 0,501 & 0.000 & 0.000 & $\begin{array}{c}\mathrm{H}_{\mathrm{a}} \text { diterima, } \\
\mathrm{H}_{0} \text { ditolak }\end{array}$ \\
\hline
\end{tabular}

Sumber: Data Olahan Peneliti, 2020.

Berdasarkan table 4 Diketahui bahwa hubungan antara brand awareness dengan keputusan pembelian produk Merchè di kalangan followers Instagram merche.id memiliki koefisien korelasi sebesar 0,708 yang menunjukan hubungan yang tinggi atau kuat. Brand awareness Merchè menunjukan pengaruh yang cukup berarti terhadap keputusan pembelian produk Merchè di kalangan followers Instagram merche.id dengan koefisien determinan sebesar 0.501. Hasil tersebut menunjukan bahwa brand awareness Merchè berkontribusi sebesar 50,1\% terhadap keputusan pembelian produk Merchè di kalangan followers Instagram merche.id. Sisanya sebanyak 49,9\% mengenai pengaruh brand awareness terhadap keputusan pembelian produk Merchè tidak terangkum dalam hasil penelitian ini yang menunjukan adanya faktor lain yang dapat mendukung brand awareness Merchè terhadap keputusan pembelian produk Merchè. 
Peneliti juga melakukan uji simultan (F-test) untuk mengetahui pengaruh brand awareness terhadap keputusan pembelian produk Merchè di kalangan followers Instagram merche.id secara bersama-sama. Berdasarkan tabel 27 diketahui bahwa $\mathrm{F}$ hitung tingkat signifikansi 0.000 yang menunjukan besarnya peluang untuk dapat menggeneralisasi persamaan regresi guna memprediksi pengaruh brand awareness terhadap keputusan pembelian produk Merchè di kalangan followers Instagram merche.id. Uji simultan atau F-test bertujuan untuk mengetahui pengaruh secara bersama-sama variabel bebas (independen) terhadap variabel terikat (dependen) sebagaimana diungkapkan (Sugiyono, 2013) bahwa apakah koefisien korelasi itu dapat digeneralisasikan atau tidak, maka harus di uji signifikansinya dengan menggunakan rumus $\mathrm{F}$.

Kesimpulan dari uji hipotesis ini menunjukan bahwa ada pengaruh signifikan brand awareness terhadap keputusan pembelian produk Merchè di kalangan followers Instagram merche.id yang ditunjukan dengan koefisien signifikansi (Sig.) sebesar 0.000. Hal tersebut menunjukan bahwa hipotesis $\mathrm{H}_{\mathrm{a}}$ diterima dan $\mathrm{H}_{0}$ ditolak. Kesimpulannya bahwa ada pengaruh signifikan brand awareness terhadap keputusan pembelian produk Merchè di kalangan followers Instagram merche.id memiliki koefisien regresi sebesar 0.501 sehingga menunjukan adanya pengaruh yang cukup berarti.

Pengaruh yang cukup berarti dari brand awareness terhadap keputusan pembelian produk Merchè di kalangan followers Instagram merche.id menunjukan bahwa brand awareness Merchè berkontribusi dengan cukup signifikan dalam meningkatkan keputusan pembelian produk Merchè di kalangan followers Instagram merche.id.

Setelah di dapatkan uji hipotesis sebagaimana di paparkan di atas, selanjutnya peneliti dapat melakukan prediksi atas pengaruh brand awareness terhadap keputusan pembelian produk Merchè di kalangan followers Instagram merche.id melalui persamaan regresi. Prediksi ini dilakukan melalui koefisien regresi yang diketahui sebagai berikut:

\section{Tabel 5}

Persamaan Regresi

\begin{tabular}{cccc}
\hline $\begin{array}{c}\text { Persamaan } \\
\text { Regresi }\end{array}$ & Konstanta & $\begin{array}{c}\text { Koefisien } \\
\text { Regresi }\end{array}$ & Keterangan \\
\hline X terhadap Y & 4.460 & 0.657 & $\begin{array}{c}\text { Rendah tetapi } \\
\text { pasti }\end{array}$ \\
\hline
\end{tabular}

Sumber: Data Olahan Peneliti, 2020.

Uji regresi juga digunakan dalam mengembangkan suatu persamaan untuk meramalkan sesuatu variabel dari variabel kedua yang telah diketahui (Arikunto, 2014, p. 338), di mana rumus persamaan dari regresi linier sederhana yaitu:

$\mathrm{Y}=\mathrm{a}+\mathrm{bX}$

Dimana:

Y : Subyek dalam variabel dependen yang diprediksikan, yang dalam penelitian ini yakni keputusan pembelian produk fashion Merchè. 
a : Harga Y bila $\mathrm{X}=0$ (harga konstan).

b : Angka arah atau koefisien regresi, yang menunjukan angka peningkatan ataupun penurunan variabel dependen yang didasarkan pada variabel independen. Bila b (+) maka naik, dan bila $b(-)$ maka terjadi penurunan.

$\mathrm{X}$ : Subjek pada variabel independen yang mempunyai nilai tertentu, yang dalam penelitian yakni merujuk pada brand awareness Merchè.

Berdasarkan hasil dari rumusan persamaan regresi di atas, dapat di prediksikan bahwa setiap penambahan brand awareness Merchè akan diikuti dengan kenaikan keputusan pembelian produk fashion Merchè sebesar 0.657 yang berarti kenaikannya cukup berarti dan positif.

Hasil penelitian menunjukan bahwa adanya pengaruh signifikan brand awareness terhadap keputusan pembelian produk Merchè di kalangan followers Instagram merche.id dengan koefisien sebesar 0.501 yang berarti pengaruhnya tersebut cukup berarti. Hasil tersebut mengindikasikan bahwa brand awareness Merchè memiliki peran penting dalam menunjang keputusan pembelian produk Merchè pada konsumen. Untuk itu brand awereness sebagai bagian dari inti pemasaran suatu merek menjadi bagian penting yang turut membangun keputusan pembeli. Di mana upaya pembentukan brand awareness merupakan bagian langsung dari serangkaian branding dalam komunikasi pemasaran.

Pemasaran online mengacu pada strategi yang digunakan untuk memasarkan produk dan layanan secara online dan melalui sarana digital lainnya. Ini dapat mencakup berbagai platform online, alat, dan sistem pengiriman konten, seperti: Konten dan desain situs web, email Pemasaran, Media sosial. (Kabani, 2013). Media online adalah cara, proses, atau media yang menghasilkan, menerbitkan, mentransmisikan, atau menyebarluaskan opini yang berorientasi pada pesan atau tematik, foto, audio visual dengan menggunakan tanda, simbol, teks, suara, grafik, lagu, musik, video, animasi, dan berbagai multi-media melalui internet (Kabani, 2013). Bagaimana pun media sosial mewakili masa depan inovasi merek dengan kemungkinan yang hamper tak terbatas untuk kinerja merek yang lebih besar (Melewar \& Nguyen, 2014).

Media sosial menjadi aspek penting dalam kaitan perusahaan dengan pelanggannya, di mana perusahaan dapat berinteraksi langsung dengan pelanggan dan calon-calon konsumen potensial melalui kedekatan interaksi media sosial. Media sosial juga dapat dimanfaatkan dalam melakukan branding oleh perusahaan melalui kontenkonten yang diunggah, sebagaimana diungkapkan (Manninen, 2017) bahwa potensi yang dipegang media sosial untuk komunikasi merek, memutuskan platform mana yang akan digunakan dan bagaimana media sosial menjadi penting bagi bisnis yang berjuang untuk menarik perhatian serta dukungan khalayak online.

Terlebih, media online sangatlah murah dalam penggunaannya sehingga banyak perusahaan menggunakannya untuk strategi promosi mereka, sebagaimana diungkapkan (Kabani, 2013) bahwa perusahaan yang mempergunakan media sosial sangat berpeluang dalam mendekatkan dirinya dengan konsumen karena media sosial bukan 
dibuat untuk pemasar/perusahaan melainkan dibuat untuk konsumen. Perusahaan dapat mengambil untung dari kedekatan tersebut, dan membangun branding di dalamnya.

Membicarakan branding, tidak terlepas dari keberadaan brand (merek) adalah konsekuensi langsung dari strategi segmentasi pasar dan diferensiasi produk dalam strategi pemasaran. Perusahaan-perusahaan yang berusaha untuk memenuhi harapan pelanggan tertentu dengan lebih baik, mereka berkonsentrasi pada diferensiasi produk, konsisten dan berulang-ulang, dengan kombinasi atribut ideal - baik yang nyata dan tidaknyata, fungsional dan hedonistik, terlihat dan tidak terlihat - di bawah kondisi ekonomi yang layak untuk bisnis mereka. Perusahaan-perusahaan menginginkan stempel mereka di berbagai sektor dan menetapkan jejak mereka pada produk mereka. Tidak mengherankan menurut (Rajagopal, 2007) bahwa kata brand adalah sarana untuk mengklaim kepemilikannya.

Brand bukan hanya apa yang tercetak di dalam produk atau kemasannya, tetapi termasuk apa yang ada di benak konsumen dan bagaimana konsumen mengasosiasikannya. Brand menurut (Kapferer, 2008) merupakan seperangkat asosiasi mental yang dipegangkonsumen, guna menambah nilai produk atau layanan yang dirasakan. Brand sekarang diakui sebagai bagian dari modal perusahaan yang melahirkan adanya konsep image, di mana merek harus di eksploitasi karena brand adalah asset tidak berwujud, asset itu menghasilkan manfaat tambahan untuk bisnis. Lebih lanjut (Rajagopal, 2007) menunjukan brand sebagian besar terkait dengan atribut produk, manfaat, nilai pakai, budaya pengguna, dan kepribadian serta perilaku pengguna. Setiap brand memiliki kronologi dan pengalamannya yang unik dan dibangun dari waktu ke waktu melalui komunikasi yang kuat dan konsisten dimana pun brand memanifestasikan dirinya dari kartu nama ke komunikasi elektronik seperti iklan televisi, internet dan media cetak, dan akhirnya ke papan iklan.

Brand memiliki kedudukan strategis dalam suatu perusahaan, mengingat brand menjadi jati diri perusahaan yang menggambarkan esensi dari kedudukan perusahaan. Berbagai upaya perusahaan yang dilakukan untuk mendapatkan pangsa pasar dan kepemimpinan dilakukan melalui upaya branding yang harus mengedepankan beberapa indikasi yang menurut (Kapferer, 2008) antara lain: 1) Mampu memunculkan ide besar, dan menarik; 2) dirasakan langsung oleh orang-orang; 3) diaktifkan oleh perbuatan dan perilaku; 4) di komunikasikan; dan 5) di distribusikan.

Pentingnya kedudukan brand menjadikan kegiatan branding diperlukan dalam upaya memperkuat kedudukan brand. Menurut (Kapferer, 2008) branding berarti lebih dari sekadar memberi nama merek dan memberi isyarat kepada dunia luar bahwa produk atau layanan seperti itu telah di cap dengan merek dan jejak organisasi. Branding membutuhkan keterlibatan jangka panjang perusahaan, sumber daya dan keterampilan yang tinggi.

Branding perusahaan dapat meningkatkan efisiensi anggaran dengan menjembatani biaya pengembangan produk dengan siklus hidup produk yang lebih pendek tanpa mengorbankan kualitas atau layanan. Ini telah menjadi tugas yang menantang bagi banyak perusahaan multi nasional karena teknologi berkembang 
dengan sangat cepat dari pada tingkat adaptasinya di kalangan konsumen. Akibatnya menurut (Rajagopal, 2007) produk dengan teknologi baru booming di pasar mengubah siklus hidup lebih pendek untuk produk yang telah ada dan yang lebih tua. Di bawah tekanan seperti itu, corporate branding adalah satu-satunya alat untuk mendapatkan kepercayaan dan nilai-nilai konsumen. Strategi ini membantu dalam mengembangkan dan mempertahankan branding perusahaan sebagai ketepatan untuk mengintegrasikan banyak merek baru perusahaan.

Pemasaran online yang di bangun melalui internet menjadi adalah sebuah seni dan ilmu yang memanfaatkan internet untuk menyampaikan sebuah pesan sehingga kita dapat membuat orang lain untuk melakukan sebuah aktivitas, dimana contoh dari aktivitas tersebut adalah membeli produk atau jasa kita (Kabani, 2013). Media online menjadi sarana yang mudah di akses dan berguna sebagai jembatan komunikasi dalam hal meningkatkan brand awareness suatu produk atau jasa dan seringkali untuk memperkuat customer service. Bagaimanapun media sosial mewakili masa depan inovasi merek dengan kemungkinan yang hampir tak terbatas untuk kinerja merek yang lebih besar (Melewar \& Nguyen, 2014).

Tujuan di balik pemasaran online adalah untuk meningkatkan lalu lintas situs web. Pemasar online selalu menemukan cara baru dan inovatif untuk menghasilkan strategi untuk mempromosikan situs masing-masing (Kabani, 2013) Media digital memungkinkan terjadinya pertukaran informasi dalam berbagai bentuk. Informasi tersebut dapat untuk tujuan seperti hiburan, ilustrasi atau komunikasi. Media digital adalah produk dari data digital yang diproses secara elektronik, disimpan sebagai file, dan ditransmisikan dalam sistem komputer dan di seluruh jaringan. Kampanye brand awareness secara digital bertujuan untuk menumbuhkan sebuah merek melalui interaksi dan distribusi konten melalui platform digital sehingga membangun kedekatan dengan konsumen.

Brand awareness merupakan serangkaian seseorang dalam mengenali atau ingatakan merek tertentu dan asosisisnya, sebagaimana diungkapkan (Hermawan, 2012) bahwa brand awareness adalah kemampuan dari seorang calon pembeli (potential buyer) untuk mengenali (recognize) atau mengingat (recall) suatu brand yang merupakan bagian dari suatu kategori produk. (Hermawan, 2012) mengatakan bahwa Brand Awareness mencakup asset-aset terpenting bisnis, yang terdiri dari asset tak berwujud (intangible asset), nama (citra) perusahaan, brand, symbol, slogan dan asosiasinya, persepsi kualitas, kepedulian brand, basis pelanggan, serta sumber daya seperti hak paten, trademark, dan hubungan dengan dealer, semuanya merupakan sumber utama keunggulan bersaing dan pendapatan di masa depan.

Kemampuan konsumen dalam mengenali atau mengingat brand suatu produk yang berbeda bergantung pada bagaimana tingkat komunikasi brand atau persepsi konsumen terhadap brand produk yang di tawarkan. Pada proses mengenali atau mengingat sebuah brand memerlukan tingkat komunikasi brand, karena melalui tingkatan tersebut, bagaimana suatu merekakan di ingat dan di ketahui oleh konsumen dapat terlihat. 
Tingkatan Brand Awareness menurut (Rangkuti, 2013) maka dapat di simpulkan bahwa brand awareness merupakan tahap-tahap dimana suatu brand diperkenalkan dan dikomunikasikan kepada konsumen sampai akhirnya brand tersebut di akui oleh konsumen melalui penggunaan produk atau jasa pada suatu brand. Brand awareness tersebut memiliki tingkatan mulai dari yang paling tinggi berupa top of mind, lalu di bawahnya brand recall, kemudian di bawahnya lagi brand recognition, dan tingkat paling akhirya ini unaware of brand.

Keputusan pembelian adalah proses berpikir yang mengarahkan konsumen dari mengidentifikasi kebutuhan, menghasilkan pilihan, dan memilih produk dan merek tertentu. Sebagaimana di ungkapkan (Schultz et al., 2018) bahwa keputusan pembelian merupakan keadaan di mana individu mengadakan proses dalam dirinya, akhirnya melakukan pembelian dengan tujuan memperoleh kepuasan dari barang yang dibelinya itu. Lima tahap yang sering dilalui konsumen ketika mereka mempertimbangkan pembelian: pengenalan masalah atau kebutuhan, pencarian informasi, evaluasi alternatif, pembelian, dan perilaku pasca pembelian.

Faktor-faktor yang mempengaruhi pembelian meliputi usia, pekerjaan, gaya hidup, status sosial dan ekonomi, dan jenis kelamin konsumen. Faktor-faktor ini secara individu atau kolektif dapat mempengaruhi keputusan pembelian konsumen. Proses keputusan pembelian ini merupakan serangkaian tahapan yang mengacu pada serangkaian tindakan dari suatu peristiwa dalam menentukan pembelian. Keputusan pembelian dikaitkan dengan upaya untuk memenuhi kebutuhan hingga kepuasan akan produk atau jasa yang dibeli. Kepuasan tersebut dinilai berasal dari beberapa alternative pilihan sehingga diharapkan akan memberikan manfaat yang lebih baik dibandingkan alternative lainnya karena keputusan pembelian dianggap sebagai pilihan di antara beberapa alternative pilihan sebagaimana di ungkapkan (Schiffman, L. G., \& Kanuk, 2014) bahwa keputusan pembelian sebagai proses pemilihan dari dua atau lebih alternative pilihan keputusan pembelian, artinya bahwa seseorang dapat membuat keputusan, haruslah tersedia beberapa alternatif pilihan.

Konsumen di percaya telah membentuk preferensi atas merek dalam alternatifalternatif pilihannya, sehingga keputusan pembelian bukan seketika itu juga di praktekan tetapi telah melalui serangkaian proses. Keputusan pembelian dianggap sebagai proses untuk memilih yang pada akhirnya sampai pada keputusan benar-benar melakukan pembelian atas satu pilihan di antara beberapa pilihan lainnya. Keputusan pembelian ini di nilai sebagai hasil akhir dari proses pembelian, sehingga keputusan pembelian merupakan keputusan akhir dari proses pembelian sebagaimana di ungkapkan (Kotler, P., \& Keller, 2010) bahwa keputusan pembelian merupakan tahap dalam proses pengambilan keputusan pembeli dimana konsumen benar-benar membeli. Pengambilan keputusan merupakan suatu kegiatan individu yang secara langsung terlibat dalam mendapatkan dan mempergunakan barang yang ditawarkan.

Keputusan pembelian merupakan tahap keputusan akhir dan merupakan hasil seleksi dari dua atau lebih pilihan alternatif. Sedangkan pengambilan keputusan merupakan kegiatan konsumen sebelum membuat keputusan akhir tersebut. Apapun 
pemahaman mengenai keputusan pembelian, pada dasarnya menunjukan adanya upaya menentukan pilihan pada sesuatu yang telah ditentukan persepsinya mengenai manfaat yang lebih baik di bandingkan yang lainnya. Sebagai sebuah proses, keputusan pembelian memiliki beberapa tahap proses hingga adanya keputusan pembelian.

Idealnya sebuah merek harus menarik pelanggan baru melalui nilai superior (dan pemasaran yang baik) sambil terus menumbuhkan pelanggan dengan memberikan kepuasan pelanggan. Mengikuti proses ini mengarah pada peningkatan keuntungan dan ekuitas pelanggan. Pemasaran ke pelanggan baru masih merupakan bagian penting dalam menjalankan bisnis, tetapi data menunjukkan retensi lebih penting. Kemungkinan menjual ke pelanggan baru berada di antara 5-10\% dibandingkan dengan kemungkinan $60 \%-70 \%$ yang dimiliki sebuah brand untuk menjual kepada pelanggan yang sudah ada.

Sebuah studi terbaru yang dilakukan oleh American Express (2020) mengungkapkan pengaruh kepuasan pelanggan terhadap retensi. Studi ini menyatakan bahwa pelanggan 33\% lebih mungkin untuk beralih perusahaan setelah hanya satu interaksi layanan pelanggan yang buruk. Tanpa pengalaman pasca pembelian yang baik, Anda kemungkinan akan kehilangan bisnis mereka di masa depan. Bahkan jika seorang konsumen membeli produk yang benar-benar mereka sukai. Di sisi lain, pelanggan yang memiliki pengalaman hebat dengan Anda $81 \%$ lebih mungkin untuk kembali lagi! Pemasaran perilaku pasca pembelian adalah yang terbaik.

Komunikasi pemasaran memperoleh pelanggan baru untuk merek dengan membangun kesadaran dan mendorong percobaan. Komunikasi pemasaran juga mempertahankan basis pelanggan merek saat ini dengan memperkuat perilaku pembelian mereka dengan memberikan informasi tambahan tentang manfaat merek. Komunikasi pemasaran membantu memindahkan produk, layanan, dan ide dari produsen ke pengguna akhir serta membangun dan memelihara hubungan dengan pelanggan, prospek, dan pemangku kepentingan penting lainnya di perusahaan. Komunikasi sangat penting untuk pemasaran karena membuat pihak diuntungkan. (Kotler, P., \& Keller, 2010).

Komunikasi pemasaran menjadi sarana perusahaan untuk melakukan rangkaian proses pemasaran yang di bangun sebagai upaya merepresentasikan merek mereka dengan tujuan membujuk konsumen untuk yakin pada produk atau jasa yang ditawarkan hingga membuka kesempatan pada adanya pembelian. Komunikasi pemasaran dilakukan dengan menjadikan komunikasi sebagai bagian pentingnya sehingga berbagai upaya perencanaan pemasaran menempatkan konsep-konsep utama komunikasi sebagai sarananya mencapai tujuan. Komunikasi pemasaran merupakan konsep perencanaan komunikasi pemasaran yang dilakukan berdasarkan adanya kesadaran bahwa nilai tambah dari suatu rencana komunikasi yang komprehensif dapat mengevaluasi peran strategis dari pesan-pesan bisnis sebagaimana di ungkapkan (Soemanagara, 2016) bahwa komunikasi pemasaran sebagai kegiatan pemasaran dengan menggunakan teknik-teknik komunikasi yang ditujukan untuk memberikan informasi kepada orang banyak dengan harapan agar tujuan perusahaan tercapai, yaitu terjadinya peningkatan 
pendapatan (laba). Komunikasi pemasaran merupakan bentuk komunikasi yang ditujukan untuk memperkuat strategi pemasaran guna meraih segmentasi luas.

Komunikasi pemasaran menunjukan bentuk penyampaian pesan yang merujuk pada nilai-nilai pencapaian keuntungan (laba). Komunikasi pemasaran juga dikaitkan dengan segmentasi, karena komunikasi pemasaran dilakukan guna menyebarkan produk atau jasa untuk lebih di maknai keberadaannya oleh segmen-segmen konsumen selaku komunikannya. Komunikasi pemasaran menempatkan pentingnya dari implementasi teknik-teknik komunikasi sebagai rencana komprehensif dari strategi pemasaran.

\section{Kesimpulan}

Berdasarkan temuan penelitian, maka simpulan dari pengaruh brand awareness terhadap keputusan pembelian produk Merchè di kalangan followers Instagram merche.id menunjukan bahwa hubungan antara brand awareness dengan keputusan pembelian produk Merchè di kalangan followers Instagram merche.id memiliki koefisien korelasi sebesar 0,708 yang menunjukan hubungan yang tinggi atau kuat. Pengujian hipotesis membutikan bahwa ada pengaruh signifikan brand awareness terhadap keputusan pembelian produk Merchè di kalangan followers Instagram merche.id dengan koefisien sebesar 0.501 yang menunjukan pengaruhnya cukup berarti.

Brand awareness Merchè berkontribusi sebesar 50,1\% terhadap keputusan pembelian produk Merchè di kalangan followers Instagram merche.id. Sisanya sebanyak 49,9\% mengenai pengaruh brand awareness terhadap keputusan pembelian produk Merchè tidak terangkum dalam hasil penelitian ini yang menunjukan adanya faktor lain yang dapat mendukung brand awareness Merchè terhadap keputusan pembelian produk Merchè. Setiap penambahan brand awareness Merchè akan di ikuti dengan kenaikan keputusan pembelian produk fashion Merchè sebesar 0.657 yang berarti kenaikannya cukup berarti dan positif.

Berdasarkan hasil penelitian, rata-rata dimensi paling rendah dari variabel brand awareness Merchè berada pada posisi unaware of brand yang menunjukan keraguan followers di Instagram Merce.id dalam mengenal produk-produk fashion Merchè maupun nama Merchè sebagai brand. Untuk itu pihak Merchè dapat lebih ditingkatkan melalui program brand activation di Instagram yang melibatkan followers secara lebih kompetitif seperti melalui kontes review produk fashion, atau Outfit of The Day (OOTD) menggunakan produk Merchè.

Berdasarkan hasil penelitian, rata-rata dimensi paling rendah dari variabel keputusan pembelian konsumen pada brand Merchè berada pada posisi pencarian informasi yang menunjukan upaya followers di Instagram Merche.id untuk mencari infromasi kelebihan dan manfaat produk fashion Merchè dibandingkan dengan produk fashion dari brand lainnya. Untuk itu sebaiknya pihak Merchè dapat memberikan informasi-informasi yang lebih lengkap dan menarik terkait produk fashion yang ditawarkan dengan menunjukan keuntungan dan kelebihannya di bandingkan produk fashion dari merek lainnya. Seperti melalui penggunaan caption yang informatif dengan 
mencantumkan detail material, ukuran, harga, dan hal lainnya yang dianggap penting untuk diketahui konsumen.

Sebaiknya pihak Merchè dapat bekerja sama dengan influencer atau selebgram dari komunitas untuk dapat menyasar segmen konsumen yang lebih spesifik dari komunitas-komunitas potensial dalam mengembangkan brand awareness Merchè di Instagram. 


\section{BIBLIOGRAFI}

Abdullah, Ma'ruf. (2015). Metode penelitian kuantitatif. Aswaja pressindo. Yogyakarta. Google Scholar

Arikunto, S. (2013). Prosedur Penelitian Suatu Pendekatan Praktik. Jakarta. Rineka Cipta. Google Scholar

Azwar, Saifuddin. (2012). Reliabilitas dan validitas. Yogyakarta: Pustaka Pelajar. Google Scholar

Hermawan, Agus. (2012). Komunikasi Pemasaran. Jakarta: Erlangga. Google Scholar

Indriani, E. (2017). Sejarah dan Perkembangan Instagram. Jurnal Ilmuti.Org, 1-7. Google Scholar

Jatilarasati, A. (2018). Tari Puji Lestari, 30 Juta Melayang Demi Memajukan Merché. https://www.tabloidbintang.com/berita/sosok/read/91022/tari-puji-lestari-30-jutamelayang-demi-memajukan-merche

Kabani, S. (2013). The Zen of Social Media Marketing: An Easier Way to Build Credibility, Generate Buzz, and Increase Revenue (New Edition). Dallas, Texas: Benbella Books Inc. Google Scholar

Kapferer, Jean Noel. (2008). The new strategic brand management: Creating and sustaining brand equity long term. London. Kogan Page Publishers. Google Scholar

Kotler, P., \& Keller, K. L. (2010). Manajemen Pemasaran: Jilid 2 (Edisi 13). Jakarta: Erlangga. Google Scholar

Kriyantono, Rachmat, \& Sos, S. (2014). Teknik praktis riset komunikasi. Jakarta. Prenada Media. Google Scholar

Manninen, Pia. (2017). Social Media as a Branding Tool: Defining the Customer Perspective. Journal of Product \& Brand Management. Google Scholar

Melewar, T. C., \& Nguyen, Bang. (2014). Five areas to advance branding theory and practice. Journal of Brand Management, 21(9), 758-769. Google Scholar

Nazir, M. (2014). Metode Penelitian (cetakan ke sembilan). Bogor: Ghalia Indonesia. Google Scholar

Pradana, Thoriq Anugrah Fatra, \& Yulianna, Eka. (2015). Pengaruh Brand Awareness Terhadap Minat Beli Konsumen Jasa Reservasi Hotel Secara Online Pada Situs Www. goindonesia. com. EProceedings of Management, 2(3). Google Scholar

Rajagopal. (2007). Brand management: strategy, measurement and yield analysis. New york. Nova Science Publishers. Google Scholar

Rakhmat, Jalaluddin, \& Surjaman, Tjun. (2012). Metode penelitian komunikasi: dilengkapi contoh analisis statistik. Bandung. Remaja Rosdakarya. Google Scholar 
Rangkuti, Freddy. (2013). Strategi promosi yang kreatif dan analisis kasus. Jakarta. Gramedia Pustaka Utama. Google Scholar

Sakinah. (2018). Selebgram: Meraih Popularitas Melalui Dunia Maya. Etnosia. Jurnal Etnografi Indonesia, 3 .(1), 48-71. Google Scholar

Schiffman, L. G., \& Kanuk, L. L. (2014). Perilaku Konsumen. Jakarta: PT. Indeks Gramedia. Google Scholar

Schultz, Konrad, Jelusic, Danijel, Wittmann, Michael, Krämer, Benjamin, Huber, Veronika, Fuchs, Sebastian, Lehbert, Nicola, Wingart, Silke, Stojanovic, Dragan, \& Göhl, Oliver. (2018). Inspiratory muscle training does not improve clinical outcomes in 3-week COPD rehabilitation: results from a randomised controlled trial. European Respiratory Journal, 51(1). Google Scholar

Soehartono, Irawan. (2011). Metode Penelitian Sosial: Suatu Teknik Penelitian Bidang Kesejahteraan Sosial dan Ilmu Sosial Lainnya, Cetakan VIII. Bandung: Rosda. Google Scholar

Soemanagara, Rd. (2016). Strategi Marketing Communication: Konsep Strategis dan Terapan(Cetakan ke empat). Bandung: Alfabeta. Google Scholar

Sugiyono. (2013a). Metode Penelitian Kuantitatif Kualitatif dan R\&D. Bandung: CV Alfabeta. Google Scholar

Sugiyono, S. (2013b). Metode Penelitian Kuantitatif Kualitatif dan R\&D. Bandung. Alfabeta. Google Scholar

Susyanti, Jeni, \& Wahono, Budi. (2018). Analisa Kinerja Keuangan Perusahaan Real Estate Dan Property Sebelum Dan Selama Diberlakukannya PP No. 34 Tahun 2016. Jurnal Ilmiah Riset Manajemen, 7(03). Google Scholar

Umar, Husein. (2009). Metode penelitian untuk skripsi dan tesis bisnis. Jakarta.Raja Grafindo Persada . Google Scholar

Yuliati, Ai Lili, \& Maulidi, Refi Agus. (2017). Pengaruh Tingkat Brand Awareness terhadap Minat Beli Apple iPhone. ISEI Business and Management Review, 1(1), 7-18. Google Scholar

\section{Copyright holder:}

Aldila Salsha Nabila, Nelly Nailatie Ma'arif (2021)

\section{First publication right:}

Syntax Idea

This article is licensed under:

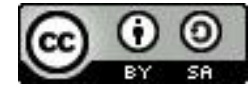

